
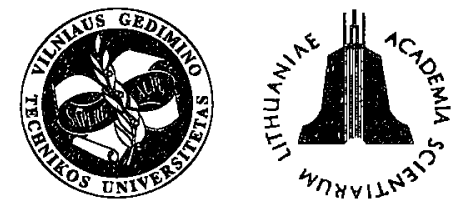

ISSN 1648-4142 TRANSPORT

http:/www.vtu.lt/english/editions

TRANSPORT - 2003, Vol XVIII, No 6, 229-240

\title{
THE IMPROVEMENT OF EXTERNAL TRANSPORT COST EVALUATION IN THE CONTEXT OF LITHUANIA'S INTEGRATION INTO THE EUROPEAN UNION
}

\author{
Margarita Išoraite̊ \\ Law University of Lithuania, Ateities g. 20, LT-2057 Vilnius, Lithuania.E-mail: misorait@ltu.lt
}

Received 200306 02; accepted 20031114

\begin{abstract}
The accepted accession to the European Union in Lithuanian internal transportation is regulated by the coordination of national legal acts with the international conventions and documents of various international organisations. This process was particularly accelerated when Lithuania started negotiations on the accession to the European Union. Future transport pricing policy of Lithuania has two objectives - to guarantee the covering of operational costs and to strive for economic efficiency. These objectives should not be coincident. Economic, institutional and legal reforms in Lithuania are implemented with the aim to co-ordinate the standards and regulations effective in Lithuania with the acts of the European Union. In the article on the basis of pricing of the peak, the social marginal, the environmental costs referring to the advanced research of Western and US scientists, were analysed and improved the evaluation of external Lithuanian transport costs and economic methods enabling the integration of external transport costs into the internal costs were offered. The improvement of external cost evaluation will enable the integration of external transport costs in line with the EU standards. One of the most actual problems of Lithuania is the growth of environmental impact and social subsequences caused by the increase of transport in Lithuania: Increasing traffic jams, air pollution, growing rates of accidents and noise emission are the main problems of the Lithuanian transport system. Thus, in transport system, besides the internal costs, there exist the external costs that are not reflected in transport cost price. These costs are caused by air pollution, worsened health condition of people, decreased agrarian fertility, increased water pollution, etc. Therefore it is necessary to evaluate these external transport costs and to propose the ways of their reduction as well as their inclusion into the transportation price. The methodological basis of the article is the method of systematic and multicriterial analysis aiming at the evaluation of the necessity of the inclusion of external transport costs into the transport price with the attitude towards the national and the carrier's positions. Research work of Western and US scientists was referred to the grounding of the necessity of external transport costs in Lithuania. Having analysed the experience of the scientists of US and Western countries, as well as the practice of Lithuanian scientists, a methodology for the evaluation of external transport costs in the country was offered. The application of the EU standards is tackled as well. Most ideas suggested in the article could be valuable for further formation and enhancement of external costs of economic technique in Lithuania thus approaching the national pricing to the EU standard system. The evaluation made in the article shall be applied for the implementation of external transport cost evaluation technique in Lithuanian transport.
\end{abstract}

Keywords: external costs of transport, price theory.

\section{Introduction}

Transport is one of the sectors of Lithuanian economy integrated into the European market. This accounts for the fact that transport presents a connectinglink facilitating the development of international trade and ensuring free movement of people and goods. The participation in the international trade decides the common peculiarities of transport activity regulation. Even internal transportation is regulated by the co-ordination of national legal acts with the international conventions and documents of various international organisations.
This process has particularly accelerated when Lithuania started negotiations on the accession to the European Union.

Future transport pricing policy of Lithuania has two objectives - to guarantee the covering of operational costs and to strive for economic efficiency. These objectives should not be coincident. Economic, institutional and legal reforms in Lithuania are implemented with the aim to co-ordinate the standards and regulations effective in Lithuania with the acts of the European Union [1]. 


\section{Analysis of External Transport Costs, Prices and Pricing Theory}

Internal and external cosis. Transportation costs are classified as internal and external costs. Internal costs of transportation emerge from the services of transportation service providers and consumers. They emerge in the process of transportation. This can not be said of external costs. The latter emerge when activities of one group make an impact on the other group without any remuneration of losses or compensation. If the loss is remunerated by compensation (as required by the Government) and an external impact is evaluated, then the external costs become internal costs [2].

Pollution - the "polluter pays" principle. Figure demonstrates optimal pollution charges regarding the noise emission. General principles may be also successfully applied to other forms of pollution, such as air and water pollution. $M P C$ means marginal private freight transportation costs (in tonnes). They comprise the work, fuel, maintenance costs. $M E C$ means marginal environmental costs indicating marginal noise impact/disturbance expressed in monetary terms in each traffic level, and $D$ is the curve of demand for transportation by road transport services. $M S C$ is the curve of marginal social costs and it demonstrates the sum of $M P C$ and $M E C$. On condition that road carriers regard their personal operating costs, then the production balance will be of the $Q_{A}$ level, and the price or costs will be $P_{A}$. However, if all the costs - personal and social are regarded, then $Q^{*}$ will be an optimal production level, and the price or costs will be $P^{*}$. The $Q^{*}$ means a marginal profit equal to the marginal social costs of transportation by road transport. The "polluter pays" principle states that carriers have to be aware of external costs, which they cause and pay pollution, charge equivalent to $M E C$. It means that some goods will be shifted to other modes or that the industrial shifting will reduce general transport production. It is unpractical to directly charge consumers for pollution, therefore for purchasing of a vehicle and for a yearly licence of the Road Fund several indirect methods were proposed, including the pollution tax. However, no method has offered an ideal "polluter pays" scheme, particularly the tax is not related to the actual use of a vehicle.

Pricing in the case of traffic jams. Primarily the idea of using the pricing for the reduction of traffic jams was proposed more than eighty years ago by Pigou (1920) [3], then slightly later by Knight (1924) [4]. The theory demonstrated that traffic jams taxes lead to the internalisation of traffic jams costs by consumers. The theory of traffic jams pricing was developed by such scientists as Walters (1961) [5], Strotz (1964) [6], Mohring (1965, 1970, 1996) [7-9], Lvy-Lamber (1968) [10], Marchand (1968) [11], Vickrey (1968) [12], Keeler and Small $(1989,1983,1992)[13-15]$ and De Vany (1976) [16], Jensen (2001) [17]. Vickrey's (1969) [18] "bottle-

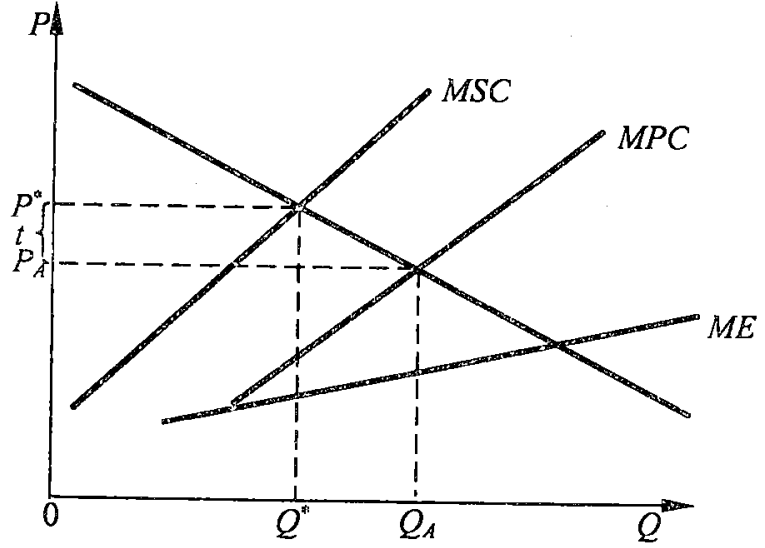

Optimal pollution tax

neck" model is particularly differently viewed by various publication sources. Basing on this method the travel time spent in traffic jams is analysed. The "bottleneck" model was renewed and vastly investigated in the articles of Arnott [19], De Palma, A. and R. Lindsey (1998, 2000) $[20,21]$ and even nowadays traffic researchers often apply the model.

Pricing of external environmental costs. Whereas the pricing of traffic jams reduces the number of kilometres covered and decreases the used fuel amounts, thus the reduced air pollution is one of its positive results. Daniel and Behha (2000) [22] investigated this impact of traffic jams taxes according to a detailed model and settled that the taxes reduce the emission of vehicles from $10 \%$ to $30 \%$ with a social profit fluctuating from $15 \%$ to $30 \%$. Parry and Bento (2001) [22] have also investigated the profit of traffic jams pricing. They focused an environmental impact and the impact of accidents. Daniel and Behha found that there is a great environmental benefit from the pricing of traffic jams ( $25 \%$ of profit from a reduced traffic jam) provided that the fuel (petrol) tax by itself will not be able to internalise the external costs of air pollution. The principles of pricing of marginal costs maintain that instead of applying the traffic jams pricing for the improvement of air condition it is necessary to carry out a special policy facilitating the improvement of these particular external transport costs. The pollution caused by one vehicle does not depend on the traffic jams.

The importance of external transport costs (Table 1) is based on the fact that in the market economy the public resources decide upon the features of pricing. If the prices reflect the shortage of goods, then principally the market will guarantee the effective distribution of resources. However, when the market prices, e.g. because of transport accidents, will reflect the existing shortcomings, such as weather purity, quality of environmental safety, infrastructure, etc., the transport demand will exceed the socially optimal standard and the distribution of 
Table 1. Classification of transport costs

\begin{tabular}{|c|c|c|}
\hline \multirow{2}{*}{ Types of costs } & \multicolumn{2}{|c|}{ Social costs } \\
\hline & Internal/individual costs & External costs \\
\hline Costs of transport services & Fuel and vehicles costs, tickets/tariffs & $\begin{array}{l}\text { Other paid costs (for instance, vehicle storage } \\
\text { costs) }\end{array}$ \\
\hline Infrastructure costs & $\begin{array}{l}\text { Consumers' fees, vehicles charges and fuel } \\
\text { excise duty }\end{array}$ & Uncovered infrastructure costs \\
\hline Costs of casualties & Covered insurance and casualties costs & $\begin{array}{l}\text { Uncovered costs for casualties (i.e. pain and } \\
\text { torments experienced by others) }\end{array}$ \\
\hline Costs of environmental safety & Own losses & $\begin{array}{l}\text { Uncovered environmental safety costs (i.e. } \\
\text { noise paid by others) }\end{array}$ \\
\hline Jam costs & Costs of own time & $\begin{array}{l}\text { Delays/time consumption costs which are paid } \\
\text { by others }\end{array}$ \\
\hline
\end{tabular}

resources will not be efficient. However the external costs are covered by others, not by transport users, i.e. by those affected by transportation: those falling ill because of air pollution, taxpayers, social insurance payers, infrastructure costs payers, etc. Thus, the price system that does not reflect proper public costs is both ineffective and improper. External costs force transport users to react towards prices that are less than proper expenses, which increase the demand for transport, which make economic effect [23-27].

Sustainable policy should be oriented towards complete internalisation of a social and environmental input. It is necessary to take decisive steps aiming at the dissociation of the growth of transport flows from the growth of GDP, particularly in redistribution of transport modes, i.e. employing more railways, water and public transport. It is necessary to gradually change the transport charges by the more efficient means integrating expenses related to infrastructure, and external costs. These means firstly comprise the infrastructure users' tax, which is a particularly efficient measure for the management of traffic jams and for the reduction of environmental impact, and, secondly, - taxes for fuel, that enable the control of carbon dioxide emission.

The main principle of the collection of a tax for infrastructure use is that the tax has to cover not only the costs related to the infrastructure, but also to the external costs, related to roads accidents, air pollution, noise emission and congestion. This concerns all transport modes and all consumers' categories, both private and commercial.

Table 2. External and infrastructure costs (2001) of a heavy vehicle moving on a motorway at $100 \mathrm{~km} / \mathrm{h}$ under the conditions of non-intensive traffic

\begin{tabular}{|l|c|}
\hline \multicolumn{1}{|c|}{ External and infrastructure costs } & Average (Euro) \\
\hline Air pollution & $2,3-1,5$ \\
\hline Climate changes & $0,2-1,54$ \\
\hline Infrastructure & $2,1-3,3$ \\
\hline Noise emission & $0,7-4$ \\
\hline Road accidents & $0,2-2,6$ \\
\hline Congestion & $2,7-9,3$ \\
\hline General & $8-36$ \\
\hline
\end{tabular}

General input should be better reflected in the structure of costs. Regarding the abundance of legal acts concerning this issue, as well as the risk of competition variation, it is necessary to implement a system defining tax payment for the infrastructure of all transport modes.

Table 2 demonstrates the indices of input of heavy vehicles moving in an open country with the speed of numbers show the input related to the air pollution (costs related to health and harvest damages), climate changes (floods and harvest damages), infrastructure, noise emission.

The foreseen measures should decrease the breach between costs and taxes. For instance, gradual tightening of standards for vehicles gas emission should reduce air pollution. Price determination related to real costs arising from different types of engines, congestion and other external factors, shall not mean that the taxes will increase to all actors. The taxes will be higher in the places with more intensive traffic if compared with less developed regions.

It is most important to alter not a general level of taxes, but to change their structure that should be radically transformed so that external and infrastructure costs were integrated into the transport price.

\section{Evaluation System of Social Subsequences and Environmental Impact of Transport Services}

Regarding the external costs it may be stated that external costs depend on the intensity of road traffic - the $100 \mathrm{~km} / \mathrm{h}$ on a highway at non-peak hours. The presented 
higher traffic, the higher external costs. Five areas are defined where road traffic increases external costs: air pollution, noise emission, accidents, use of land, road infrastructure. Air pollution and vehicles make an impact not only on the flora and fauna, people's health, but also on buildings, constructions, on water and soil, as well as on climate changes. Noise impacts the comfort of home as well as industry/production. For noise reduction additional funds are necessary for purchasing and installation of noise reducing insulation materials. Noise emission also makes a negative impact on recreation and tourism as well as on public health conditions. People do not wish to live in hotels or houses situated close to railway or bus stations and airports. Prices of flats and hotels situated near such objects are comparatively low. Accidents exercise not only a negative impact on public health condition - the society suffers material losses caused by road accidents. For instance, the overturn of a vehicle with dangerous goods causes a spill of hazardous materials. Use of land also makes a negative impact on soil as well as on general landscape. With the growth of road traffic the road infrastructure gets overloaded. This fact is responsible for the costs of traffic jams. Increased traffic also increases the uncovered infrastructure costs.

If a transport user pays for the resources of use (e.g. use of energy and infrastructure), these costs may be considered as internal costs. If a transport user makes an impact on the welfare of others (e.g. by polluting the air) without paying for that, then for others such costs become external costs. There is a clear relation to the principle "polluter pays", when the costs for pollution have to be covered. The fact that solutions in the market economy depend very much on market prices has particular importance to external transport costs. Therefore pricing based on full social expenses is the principal ele- ment of an effective and sustainable transport system.

Table 3 demonstrates constituent parts of costs of all transport modes. Regardless of different technologies it is possible to compare three categories by defining them as: infrastructure costs, users activity costs (users monetary and users travel time costs), carriers activity costs and social costs.

The formula is applied with the aim to develop the Ferrari's transport costs definition model. It would be expedient to develop this model and to apply it for the determination of transport prices in bigger Lithuanian towns, such as: Vilnius, Kaunas, Klaipeda. According to the formula of costs determination, a transport enterprise has the costs of peak and non-peak services activity, the costs of changing a certain route or route service activity and the indicated route costs (including the wear of vehicles and buildings). The costs of peak and non-peak time supply information for determination of the peak and non-peak time tariffs. Information on the costs of activity is necessary for the definition of the activity deficit, the standards of tariffs and for the evaluation of changes proposed in a certain route service. While the distributed costs may be used for the evaluation of the capital used by a transport enterprise.

It is purposeful to calculate the costs of transport enterprise in bigger Lithuanian towns according to the following formula:

$F C_{i t}=C_{1 m} M_{1 i t}+C_{2 m} M_{2 i t}+C_{1 p} P_{1 i t}+C_{2 p} P_{2 i t}+f_{1 i}^{n c} C_{N C t}+f_{2 i}^{n c} C_{N C t}$

$f_{1 i}^{C} C_{C t}+f_{2 i}^{C} C_{C t}, i=1,2, \ldots, I$;

where: $F C_{i t}$ - fully distributed costs for the $i$-th route at the $t$ time period; $C_{1 m}$-average costs of the systemrelated peak time vehicle $\mathrm{km}$ (1 identifies a peak time period); $M_{1 i t}$ - services delivered by the vehicle $\mathrm{km}$ at

Table 3. Constituents of costs of transport sectors

\begin{tabular}{|c|c|}
\hline $\begin{array}{l}\text { Road } \\
\text { transport }\end{array}$ & $\begin{array}{l}\text { Infrastructure costs - costs of land, capital, management, road signs maintenance } \\
\text { Users costs - costs of vehicle ownership and activities, costs of time } \\
\text { Carrier's costs } \\
\text { External costs - costs of air pollution, noise, safety, traffic jams }\end{array}$ \\
\hline $\begin{array}{l}\text { Air } \\
\text { transport }\end{array}$ & $\begin{array}{l}\text { Costs of aviation system: capital and management costs } \\
\text { Airport costs - costs of land, capital, maintenance, activities } \\
\text { Carrier's costs } \\
\text { User's costs - costs of time - time consumption } \\
\text { External costs - costs of air pollution, noise emission, safety, traffic jams }\end{array}$ \\
\hline $\begin{array}{l}\text { Railway } \\
\text { transport }\end{array}$ & $\begin{array}{l}\text { Infrastructure costs - costs of land, railway capital, management and maintenance costs } \\
\text { Rolling stock fleet costs - costs of capital, activities, maintenance } \\
\text { User's costs - time costs - time consumption } \\
\text { Carrier's costs } \\
\text { External costs - costs of air pollution, noise emission, safety, traffic jams }\end{array}$ \\
\hline $\begin{array}{l}\text { Maritime } \\
\text { transport }\end{array}$ & $\begin{array}{l}\text { Infrastructure costs - capital, management costs } \\
\text { Port costs - costs of land, capital, maintenance costs, activities costs } \\
\text { Carrier's costs } \\
\text { User's costs - costs of time - time consumption } \\
\text { External costs - costs of air pollution, noise emission, safety }\end{array}$ \\
\hline
\end{tabular}


the peak time for the $i$-th route at the time period of $t$; where $C_{2 m}$ - average system-related non peak time vehicle $\mathrm{km}$ costs ( 2 identifies a non-peak time period); $M_{2 i t}$ - non-peak time vehicles services delivered at the $i$-th route $\mathrm{km}$ at the time period of $t ; C_{1 p}-$ average system-related costs of peak time passengers; $P_{1 i t}$-peak time passengers transported by the $i$-th route at the $t$ period of time; $C_{2 p}$ - average system-related costs of non-peak time passengers; $P_{2 \text { it }}$ - passengers of non-peak time transported by the $i$-th routes at the $t$ time period; $f_{1 i}^{n c}$ - ratio (or fraction) of additional non capital costs of enterprise suffered at the $i$-th route on the peak time of service; $C_{N C t}-$ general non capital costs of enterprise during the time period $t ; f_{2 i}^{n c}$ - ratio of enterprise's additional non-capital costs (fraction), obtained at the $i$ th route $t$ non-peak time of service; $f_{1 i}^{c}$ - ratio (or fraction) of enterprise's capital costs derived at the $i$-th route at the peak time of service; $C_{C t}$-general additional capital costs of enterprise during the period $t ; f_{2 i}^{c}-$ ratio (fraction) of additional costs of enterprise capital which suffered at the $i$-th route at non-peak time of services.

The present system of charges of different transport modes in the EU countries does not induce the further efficiency and strengthening of the European transport system. Charges/taxes paid by road users significantly exceed the infrastructure costs. The average of road costs makes $1 \%$ of GDP of the EU. Total revenues from road users (customs duties, vehicle tax and fuel dues) equal 2 $\%$ of GDP of the EU. Average level of costs covered in European railways reaches $56 \%$. Coverage of railway costs is under research because the ratio of their correction is not clear regarding the public services of railways. Transport charges/taxes should be precisely related to the coverage of infrastructure costs and to the external costs. To build or not to build an airport, seaport, road or railway infrastructure - this decision rests on the balance between all social costs and the increase of income. Infrastructure costs that are not covered have to be included into the transport price.

Social costs of traffic jams. With the development of the sector of new transport modes and the reduction of congestion in towns, there is a system of identification of taxation for use of urban infrastructure (e.g. parking fee).

Delays are caused when:

- a bridge is closed (its portentous condition) and the route has to be by-passed;

- a bridge is under repair and reconstruction, which causes traffic restriction.

The economy of losses of time/time consumption value for the bridge is calculated as follows:

$$
L S=E I \times G \times V K
$$

$E I$-traffic intensity (vehicle/hour); $G$ - delay (vehicle); $V K$ - average price of traffic flow (LTL/h):

$$
G=\frac{4\left(L_{0}-a\right)}{v_{0}-v_{1}}+\frac{L_{v}+2 a}{v_{1}} p+t-\frac{2 L_{0}+L_{\nu}}{v_{0}} ;
$$

$L_{0}$-distance $(\mathrm{km})$ from the bridge to the sign indicating the need to slow down speed; $L_{\nu}$ - the above and below length $(\mathrm{km})$ of bridge (viaduct); $\nu_{0}$ - speed of vehicle $(\mathrm{km} / \mathrm{h})$, when bridge is not closed; $v_{1}$-speed of vehicle $(\mathrm{km} / \mathrm{h})$, when traffic goes on the bridge; $a$-distance on both sides of bridge; $p$-coefficient; (when at the stretch $\left(L_{v}+2 a\right)$ there is one traffic lane $p=2$, when two lanes $-p=1) ; t$ - interference with traffic (h), caused by the vehicle shifting traffic lanes.

The average price of traffic flow is calculated as follows:

$$
V K=\frac{\sum_{i=1}^{9}\left(a_{i} b_{i}\right)}{\sum_{i=1}^{9} a_{i}}
$$

$a_{i}-24$ hours traffic intensity, vehicles per day; $b_{i}$ - time value of vehicles, LTL/h.

Road users' losses caused by traffic hindrances during the time of work are calculated by the following formula:

$$
Q=\left(L \times t_{p}+3\right) \times E I \times q \times L / \Delta v ;
$$

$Q$ - road users' losses caused by the traffic hindrances during the surface handling installation work, LTL; $L-$ length of road stretch, $\mathrm{km} ; t_{p}+3$-average term of speed limitation on the object (basing on experience of regional enterprises), the time duration of simple surface handling work in $1 \mathrm{~km}$ stretch of the road $-1,33$ of 24 hours, that of handling with levelling layer $-2,33$ of 24 hours, plus 3 more days for the speed limitation signs staying in place; $E I$ - average yearly vehicles traffic intensity per 24 hours, vehicles per 24 hours; $q$-average price of 1 hour of vehicle delay time $q=14,52 \mathrm{LTL} / \mathrm{h} ; \Delta v$ - average slow down of vehicles' flow caused by speed limitation applied during the repair time.

The delay of standing and waiting may be calculated by the method of modelling of traffic flows on road crossing. The method is based on the distribution model of Puason, which is used for forecasting of random incidents at a certain time period. In this case an incident is the vehicles passing through the road crossing.

Puason's distribution is expressed by the following function:

$$
p(m / \lambda)=P(X=m / \lambda)=e^{-1} \lambda / m
$$

$m$ - the number of incidents at a certain period of time; $\lambda$ - average intensity of traffic of the investigated direction during a certain period of time.

Modelling is applied in two cases: at peak hours (6 
hours per 24 hours) and at non-peak hours. During the modelling the moments of passing the road crossing in different directions are determined in line with the requirements of road traific rules and, after the evaluation of queuing, the delays are calculated. Time value should be recalculated every three years.

Evaluation of noise emission costs. Traffic noise causes health probiems. Noise interferes with mental activities. According to the World Health Organisation the noise emitted by transport is able to cause serious discomfort, as well as speech inhibition, high blood pressure, impact sleep, a stress. Road traffic is the greatest source of noise. Traffic noise causes problems at home, at work place, at school as well as in recreation areas. Therefore the improvement of transport means technology may be one of the ways towards the reduction of road traffic noise. The improvement of transport means technology and better planning of infrastructure plays a very important role in the reduction of noise emission. Producers of all transport means/vehicles make vast research into the reduction of noise (engine/tyre noise). However even such a measure as lowered speed limits will have small-scale influence if the road traffic and particularly that of heavy transport vehicles is not constantly perfected.

Economic evaluation of the negative impact of noise. Negative impact of noise exercised on human beings is evaluated on the basis of provisional typical methodology. The evaluation is made of the noise emission sources, as well as of the spread of noise over a territory and of the level of noise isolated by the window. This may be differentiated according to habitable or cultural and domestic purpose premises.

Losses of people living in the acoustic discomfort zone are identified according to the following formula:

$$
Y_{d}=B(1) \times N_{g}(1)
$$

where $B(1)$ - losses in LTL per capita per year regarding the noise level of premises in day time; $N_{g}(1)$ - number of inhabitants in the relevant zone at day.

Losses in LTL per capita per year regarding the noise level of premises, $L_{c l}$ are found out by the following:

$$
B(1)=10 \times\left(0,03 \times L_{d}\right)-5,3 .
$$

If the night transport flows were investigated, the losses caused by the noise at night-time would be identified.

Costs of transport accidents. There are great public regulation efforts aiming at the reduction of risks of accidents, irrespective of a model. Road transport accident rates receive the most attention, if compared with other transport modes. Risk of accidents and their costs depend on many factors, such as: indices of transport means, road type, driver's characteristics, driver's behaviour, speed of vehicle, kilometres covered, traffic conditions, weather conditions.

Such costs of accidents are important for the policy of pricing, which are not covered by vehicle insurance premium, i.e. by a share of costs for hospital, production losses, loss of life. A great share of costs of accidents is already evaluated, however for defining external costs it would be purposeful to introduce measures promoting the decrease of accidents.

The main costs caused by accidents are the following: medical costs (e.g. hospital); costs of losses of production; material costs (e.g. vehicle repair costs); transportation costs (police, fire brigade, legal administration); insurance costs (vehicle, road, driver's education, etc.); non-material danger (personal grief for relatives, friends); costs caused by casualties or injuries of persons. In many countries a significant share of these costs is precisely defined and, directly or non-directly, it is reimbursed by those related to the accidents. Material costs are covered by vehicle insurance or directly by the owner. Insurance costs are reimbursed either by the owner of the vehicle or by the state (including infrastructure costs). Medical costs are covered by vehicle insurance. The remaining share of medical costs and components of other costs is considered as external costs. They are allocated/distributed for traffic accidents. Following the present evaluation made by Dutchmen, a share of external costs in the context of common costs of accidents (including nonmaterial danger) ranges between $15 \%$ and $25 \%$.

Costs of transport air pollution. Irrational use of natural resources, destruction of ecological balance may cause crucial changes in the habitation areas of human beings. There is no more activity of economy left that would not cause ecological subsequences. From the environmental point of view the contradiction between human beings and the nature grows and causes more and more problems - local as well as global. Therefore industrialists, politicians and citizens have consolidated their efforts seeking to retain our environment intact. These processes take place in the perspective of possible dramatical consequences and certain negative changes may impact our economy, which would cause the lowering of social life standards. Many industrial countries managed to reach a number of significant achievements in the reduction of environmental pollution. It is generally important to maintain the desirable environmental standards. One must admit that a great amount of efforts put for the reduction of environmental pollution is destined to the correction of former environmental mistakes. However, in the mass it is very important to retain the desirable quality of the environment [28-31].

Transport impact on the environment is evaluated by 4 stages. In the first stage the transport emission is calculated and the driving conditions are evaluated, also the types of vehicles are determined by the fuel used (diesel or petrol). In the second stage the concentration in 
local or regional zones is identified. In the third stage the transport impact is evaluated, i.e. acute and chronic illnesses, attacks of asthma, taxes for hospitals and damage of production. In the fourth stage the costs of harm exercised by transport are evaluated.

Economic evaluation of the negative impact of gas emission. Losses of economy, which are caused by the environmental pollution by gas emission are expressed in monetary terms regarding urban zones and are defined by the formula:

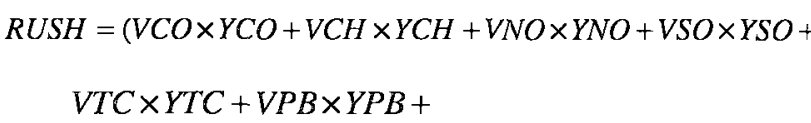

where $V C O$ - amount of exhausted pollution $\mathrm{CO}, \mathrm{kg} / \mathrm{h}$; $Y C O$ - losses, LTL/t.; $A K Z$ - multiplier for territory evaluation; IKPR - multiplier for evaluation of a street type.

At present in Lithuania the only existing regulation means of mobile pollution consists of fuel quality standards, vehicle pollution control programme (technical vehicles inspections and random road-side checks of gas emission), as well as customs duties for imported vehicles. In Lithuania the fuel standards in force are nearly adequate to the standards defined by the EU. The excise duty is not differentiated for fuels of different qualities. Most often in other countries the fuel tax is differentiated for leaded petrol and non-leaded petrol. Other regulation means existing in Lithuania are: pollution exhaust tests during the technical maintenance inspection of vehicles and fixed standards of exhaust. These fixed standards of pollution in exhausted gas are checked every two years during the technical maintenance inspection of vehicles. Whereas vehicles are not produced in Lithuania, it is more important to control pollution during operation and to ensure the conformity of imported vehicles to the EU type approval of the date of their making.

\section{Application of the EU External Costs Evaluation Practice in Lithuania}

Fuel quality is an important factor of pollution reduction. In the European Union there are in force the legal acts comprising only those fuel components, which have an impact on air pollution emission (lead and sulphur combinations). In some EU member countries the supplementary legal requirements are in force for different fuel characteristics, but in most countries other indices are regulated by the market. Oil refining companies interested in forming a positive public image strive to ensure a good quality of fuel.

While products are submitted to the market, besides the guaranty of quality their samples are analysed, their specific, legally regulated parameters are checked (if an oil refinery is in a EU country, the product is tested at once, in other cases - while importing). These legal requirements are applied to the products reaching the market. Whereas the system of quality standards controls the production processes. The legal basis for these requirements consists of the EU quality standards regulating the share of lead and sulphur combinations in fuel.

'Quality standards of oil products' are very important for the preventive regulation of transport and energy emissions. The standards limit the quantities of sulphur, lead, aromatic hydrocarbon substances. The standards meet the EU requirements.

In the course of the implementation of pollution reduction policy and the implementation of the EU requirements, since 1 January 1998 by the Decree of the Ministry of Economy obligatory indices of fuel quality have been determined for the petrol and diesel fuel used in the country. The use of leaded gasoline was also prohibited. The rate of sulphur in diesel fuel is determined not to exceed $0,05 \%$.

For ships carrying hazardous and dangerous goods (liquid or packed up) supplementary requirements are defined by the Klaipeda State Seaport shipping and Būtinge Terminal shipping rules/regulations.

All environmental safety methods may be divided into the methods of direct control and economical methods. Methods of direct control are based on the application of administrative-legal measures (environmental quality standards, limitations, prohibitions, permissions).

The advantages of administrative methods are in their transparency, clearness and easy application. However they are not flexible and not economically effective from the public point of view. But the most important fact is that they do not meet the requirements of the principle of equivalence. Such regulation often locks further technical development towards the non-polluting technologies, because companies do not have incentives for exceeding the defined control tasks based on existing standards and existing technologies. This is particularly characteristic of all countries with the authoritarian type of economy.

Economic measures may be divided into: ecological taxes, selling of permissions for pollution, ecological insurance, application of pricing mechanisms, subsidies, tax exemptions, policy of credits, compensation for suffered damages, systems of returning deposits, customs duties, fines.

It is important to define further trends of transport pollution reduction. The main trends of transport pollution reduction are the following: the preparation of plans of measures for saving energy of all transport modes; the development of urban public transport and trolley-buses in particular; further electrification of Lithuanian rail- 
ways; the development of biotransport in Lithuania; the establishment of a certification centre for certification of vehicles and their strategic parts as well as their operation; the creation of the liquid fuels quality management system; the preparation of transport standards meeting the standard requirements of the European Union and ensuring of their implementation.

Traffic jams cause public problems. Growing amounts of vehicles increase this problem in Lithuania. In London, for the solution of the problem of traffic jams, the town is divided into several zones. According to this division it is most expensive to drive in the central zone of London. In the central zone the prices of public transport tickets are the highest. Therefore, seeking to solve the problem of traffic jams in Vilnius, Kaunas and Klaipeda it is necessary to:

1. divide the town into zones;

2. introduce in public transport the peak and nonpeak time tariff.

Tariffs of peak pricing would enable:

1. the reduction of traffic jams;

2. saving of money for low-income people.

The promotion of bicycles in Lithuania is in line with the European Union policy:

- It helps to reduce the emissions of $\mathrm{CO}_{2}$ and other harmful materials.

- It is in line with the requirements set in the European Commission's 'Green Paper' dedicated to strengthening of citizens' role in the EU institutional structures. The requirements are the following:

- to guaranty free movement of European inhabitants regarding the economic, social and ecological factors;

- to reach better macroeconomic results by saving funds in the field of public health;

- to reduce investments into transport infrastructure and its operation;

- to avoid additional costs caused by a long-term negative environmental impact.

In the Lithuanian strategy of environmental safey in the field of air safety the objective to 'reduce pollution by transport emitted gases' is defined. The reduction of pollution from mobile sources should lead to the use of vehicles meeting the EU standards. It should go together with the implementation of traffic flows regulation system and other measures of pollution reduction. The following principal priorities should be observed in a transport sector:

- Gradual progress towards the use of fuels meeting the EU requirements;

- Creation of independent national control system of fuel quality;

- Implementation of emitted gases neutralisation system;

- Promotion of the use of alternative fuels, etc.
Transport is responsible for the main share of urban noise. Transport noise causes discomfort not only for inhabitants, but for workers of various institutions and enterprises as well. Noise causes discomfort to small children, school children, especially in training and educational areas and in recreation zones. Standards of noise rate in Lithuania slightly differ from those of the EU. Contrary to the EU, where the noise emission from environment is restricted, in Lithuania the rate of noise is determined by the highest permissible noise in living quarters or in working surroundings. Noise makes a direct impact on human health and on the quality of habitable and recreation areas. A particularly high negative impact on environment is exercised by transport as a dynamic source of noise. Physical noise parameters consist of the intensity of noise source (dB), frequency spectre of noise source $(\mathrm{Hz})$, noise spread in the territory, noise reflections basing on the laws of construction, physics and acoustics. A negative impact of noise reveals itself by the decrease of hearing ability (in the case of long exposure to permanent noise source). A human ear reacts differently towards noise sources of different frequencies. Principal noise sources are the flows of road transport in streets. In certain cases they generate up to $80-82 \%$ of a general noise level in urban territories. Transport flows are dynamic noise sources. They practically make a negative impact on all urban territories: dwelling-places, hospitals, sanatoriums, recreational zones, urban centres, as well as on communal and industrial territories.

For the evaluation of external transport costs in Lithuania a method of multicriterial analysis was offered. One of the most important stages of multicriterial analysis consists of defining alternative qualifying meanings and significance of the criteria. After the calculation of meanings and significance of the criteria and by the application of methods of multicriterial analysis, the priority of compared variants, their efficiency level and value are determined. Calculations are performed with the attitude towards the positions of the state and the carrier. The aim of calculations is to determine the variant more properly in regard to the carrier and the state - external costs covered by the state and external costs not covered by the state. The selection of the best variant was analysed from the point of view of state and a carrier. Two variants were taken: when the state covers the external transport expenses and, when the state does not cover them. The variants were evaluated according to the further presented quantitative and qualitative criteria. Aiming at the identification of evaluations and the significance of the criteria a questionnaire of experts was employed. Basing on the summed up results of the experts' questionnaire the significance of every criterion was defined. The mechanism of multicriterial complex proportional evaluation of integration of external costs into the transporta- 
tion price in the road transport regarding the carrier and the state is presented. The results of the questionnaire poll of experts were processed and analysed. After the calculations of significance indices the level of priority and efficiency was identified. From the carrier's point of view it is more useful for the carrier when external costs of transport are covered by the state, i.e. in such case the efficiency level equals to $100 \%$. Regarding the carrier the efficiency level is sufficiently low when external costs of transport are not covered by the state and it reaches $56,34 \%$. Comparing the variants from the state's point of view, when the state covers or does not cover external costs of transport, the priority is given to such variant when the state does not cover external expenses of transport. Comparing both views - that of the state and that of the carrier - it is possible to maintain that from the point of view of the state, when the state does not cover external costs of transport, it approaches to the pricing of social marginal transport costs.

With a view of integration of external costs into the transport price, when the monetary value of such costs is not known, the criteria may be defined and the evaluation is made of the efficiency of this or that tax.

Multicriterial evaluation may be performed with the aim of evaluation whether it would be useful to introduce a tax for the use of one or other road. Multicriterial analysis is an efficient method of presenting the data having qualitative or quantitative information. Multicriterial analysis of external cost evaluation variants was performed in the following stages:

- Questionnaire poll and forming of data base;

- Identification of the nomenclature, meanings and significance of qualitative characteristics;

- Making alternative variants of evaluation of external costs;

- Identification of significance of criteria;

- Multicriterial analysis of variants of evaluation of external costs;

- Summary of the results.

\section{Description of criteria}

1. Introduction of noise reduction tax. It is a cri- terion introduced for the reduction of traffic noise. Its purpose is to enlarge funds for purchasing noise control means, such as road isolation. Noise caused by transport may be reduced by the following means: traffic regulation, planning of road infrastructure, distance from inhabited areas, designing of roads in cuttings, bulwarks, noise isolation walls, windows insulation.

2. Costs of reduction of accidents. Costs of accidents include the whole number of costs, such as: medical, loss of production, materials, transportation, insurance, non-material dangers, personal losses and injures.

3. Covering of uncovered infrastructure costs. This criterion demonstrates that for covering of these costs it is necessary to relate them to the covering of infrastructure costs.

4. Air pollution costs. External costs of transport pollution have to be based on the air pollution emission. It is done by defining charges which are directly based on emission.

5. Costs of traffic jams. Aiming at their reduction it is necessary to introduce the tax for traffic jams. There are many measures restricting traffic jams, such as restrictions of vehicles parking, public transport subsidies, decisions on land use aiming at fighting jams.

6. Transportation price per 1 passenger $\mathrm{km}$. It shows the cost of transportation of a passenger by $1 \mathrm{~km}$.

7. Traffic jams charges/taxes. Introduction of the traffic jams charges/taxes would increase the price of public transport ticket at peak hours, and would decrease it at non-peak time.

Tables 4-7 demonstrate the results obtained by the application of the method of multicriterial analysis. The results obtained demonstrate that the integration of external costs into the transportation price, when the costs are not covered, proves to be $10,89 \%$ more efficient from the point of view of the state. The multicriterial analysis enables the solution of numerous problems. This research deals with the calculations considering not only the position of the state, but regarding the position of the carrier as well.

Table 4. Increase of transportation price determined by the internalisation of external costs in regard to the carrier

\begin{tabular}{|l|c|c|c|c|c|}
\hline \multicolumn{1}{|c|}{ Title of criterion } & $*$ & Measure & $\begin{array}{c}\text { Significance of } \\
\text { criterion }\end{array}$ & Not covered by state & Covered by state \\
\hline Noise reduction tax & - & Points & 0,3 & 5 & 7 \\
\hline Reduction of accidents & + & Points & 0,1 & 7 & 9 \\
\hline $\begin{array}{l}\text { Not covered costs of } \\
\text { infrastructure }\end{array}$ & + & Points & 0,1 & 7 & 8 \\
\hline Costs of air pollution & - & Points & 0,3 & 8 & 9 \\
\hline Costs of traffic jams & - & Points & 0,2 & 6 & 7 \\
\hline $\begin{array}{l}\text { Transportation costs for 1 } \\
\text { km }\end{array}$ & + & LTL/km & 1 & 0,12 & 0,14 \\
\hline
\end{tabular}


Table 5. Multicriterial analysis of alternatives in regard to the carrier.

\begin{tabular}{|c|c|c|c|c|c|}
\hline \multirow[b]{2}{*}{ Criteria analysed } & \multirow[b]{2}{*}{ * } & \multirow[b]{2}{*}{ Measure } & \multirow{2}{*}{$\begin{array}{l}\text { Criterion of } \\
\text { significance }\end{array}$} & \multicolumn{2}{|c|}{ Compared variants } \\
\hline & & & & \begin{tabular}{|c|}
$\begin{array}{c}\text { Not covered by the } \\
\text { state }\end{array}$ \\
\end{tabular} & Covered by the state \\
\hline Noise reduction tax & - & Points & 0,3 & 0,1250 & 0,1750 \\
\hline Reduction of accidents & + & Points & 0,1 & 0,0438 & 0,0563 \\
\hline $\begin{array}{l}\text { Non covered } \\
\text { infrastructure costs }\end{array}$ & + & Points & 0,1 & 0,0467 & 0,0533 \\
\hline Air pollution costs & - & Points & 0,3 & 0,1412 & 0,1588 \\
\hline Traffic jams costs & - & Points & 0,2 & 0,0923 & 0,1077 \\
\hline $\begin{array}{l}\text { Transportation costs for } \\
1 \mathrm{~km}\end{array}$ & + & $\mathrm{LTL} / \mathrm{km}$ & 1 & 0,4615 & 0,5385 \\
\hline \multicolumn{4}{|c|}{ Sum of maximising normalised evaluated indices $S_{+j}$} & 0,5520 & 0,6481 \\
\hline \multicolumn{4}{|c|}{ Sum of minimising normalised evaluated indices $S_{-j}$} & 0,9105 & 0,4415 \\
\hline \multicolumn{4}{|c|}{ Significance $Q_{i}$} & 0,8785 & 1,5594 \\
\hline \multicolumn{4}{|l|}{ Priority } & II & $\mathrm{I}$ \\
\hline \multicolumn{4}{|l|}{ Efficiency degree $N_{j}$} & $56,34 \%$ & $100 \%$ \\
\hline
\end{tabular}

Table 6. Growth of transportation costs determined by the internalisation of external costs regarding the state

\begin{tabular}{|l|c|c|c|c|c|}
\hline \multicolumn{1}{|c|}{ Title of criterion } & $*$ & Measure & $\begin{array}{c}\text { Significance of the } \\
\text { criterion }\end{array}$ & Covered by state & Non-covered by state \\
\hline Noise reduction tax & + & Points & 0,3 & 7 & 9 \\
\hline Reduction of accidents & - & Points & 0,2 & 8 & 9 \\
\hline $\begin{array}{l}\text { Coverage of non-covered } \\
\text { infrastructure costs }\end{array}$ & + & Points & 0,3 & 7 & 8 \\
\hline Air pollution costs & - & Points & 0,1 & 9 & 7 \\
\hline Traffic jams charges & + & Points & 0,1 & 6 & 9 \\
\hline $\begin{array}{l}\text { Transportation costs per 1 } \\
\text { km }\end{array}$ & + & LTL/km & 1 & 0,13 & 0,14 \\
\hline
\end{tabular}

Table 7. Multicriterial analysis of alternatives in regard to the state

\begin{tabular}{|c|c|c|c|c|c|}
\hline \multirow[b]{2}{*}{ Criteria analysed } & \multirow[b]{2}{*}{ * } & \multirow[b]{2}{*}{ Measure } & \multirow[b]{2}{*}{$\begin{array}{l}\text { Criterion of } \\
\text { significance }\end{array}$} & \multicolumn{2}{|c|}{ Compared variants } \\
\hline & & & & Covered by state & $\begin{array}{l}\text { Non-covered by } \\
\text { state }\end{array}$ \\
\hline Noise reduction tax & + & Points & 0,3 & 0,1313 & 0,1688 \\
\hline Reduction of accidents & - & Points & 0,2 & 0,0941 & 0,1059 \\
\hline $\begin{array}{l}\text { Coverage of uncovered } \\
\text { infrastructure costs }\end{array}$ & + & Points & 0,3 & 0,14 & 0,16 \\
\hline Air pollution costs & - & Points & 0,1 & 0,0563 & 0,0438 \\
\hline Traffic jams charge & + & Points & 0,1 & 0,04 & 0,06 \\
\hline $\begin{array}{l}\text { Transportation costs per } 1 \\
\mathrm{~km}\end{array}$ & + & $\mathrm{LTL} / \mathrm{km}$ & 1 & 0,4815 & 0,5185 \\
\hline \multicolumn{4}{|c|}{ Sum of maximising normalised evaluated indices $S_{+j}$} & 0,7928 & 0,9073 \\
\hline \multicolumn{4}{|c|}{ Sum of minimising normalised evaluated indices $S_{-j}$} & 0,1504 & 0,1497 \\
\hline \multicolumn{4}{|c|}{ Significance $Q_{j}$} & 0,9424 & 1,0576 \\
\hline \multicolumn{4}{|l|}{ Priority } & II & I \\
\hline \multicolumn{4}{|l|}{ Efficiency degree $N_{j}$} & $89,11 \%$ & $100 \%$ \\
\hline
\end{tabular}

* Mark $+(-)$ shows that a relatively higher (lower) meaning of the criterion is more relevant to the carrier's requirements. 


\section{Conclusions}

1. The inclusion of marginal external costs of transport into the prices of transport services will enable more precise assessment of national revenues generated in transport sector.

2. The application of the systematic method and multicriterial complex evaluation method and the inclusion of external costs into the price of transport services allows:

a) more objective setting of national budget;

b) a carrier to look for more economic ways for the reduction of prices of transport services, which will improve not only carriers' financial indices, but will also allow him to last under heavy conditions of the market and competence.

3. In the course of integration of external costs of transport services into the pricing of transport, the external costs become internal costs and in the carrier's accounts of costs all social marginal costs of transport are reflected.

4. It would be expedient to apply the principle of marginal costs for the improvement of the determination of transportation price, which would allow to reflect the costs of social subsequences in the price.

5. The inclusion of external costs into the pricing of transportation on the one hand would increase the price of such a service, however on the other hand it would induce the carrier to search for possibilities to reduce these costs:

5.1. To improve environmental quality (by the introduction of customs duties for imported old cars);

5.2. to reduce traffic jams (applying the Ferrari model of price definition, it is necessary to specify the price of transport services and to introduce appropriate peak time charge);

5.3. after the introduction of noise charges the noise rate will decrease;

5.4. after the introduction of infrastructure charges for the use of railway infrastructure the funds will be found for the improvement and development of railway infrastructure;

5.5. the losses caused by accidents being included into the road, railway, water, air transport infrastructure charges the uncovered costs of accidents will gradually decrease.

\section{References}

1. Išoraite, M. Application of EU transport pricing policy in Lithuania. Transport (Transportas), Vilnius: Technika, Vol XIV, No 4, 1999, p. $200-206$.

2. Išoraitè, $M$. From external costs towards fair and efficient pricing. In: Proceedings of the conference. 'Set of scientific reports of International Conference 'Nordic-Baltic
Transport Research Conference' that took place in Riga on 13-14 April 2000. Riga, 2000, p. 1-5.

3. Pigou, Arthur C. The Economics of Welfare, first edition, Macmillan Company, London, 1920.

4. Knight, F. H. Some fallacies in the interpretation of social costs. Quarterly Journal of Economic, 1924, Vol 38, p. 582 606.

5. Walters, Alan A. Theory \& measurement of private \& social cost of higway congestion. Econometrica, Vol 29, No 4, p. 676 699. Reprinted in Readings in Urban Economics, eds., Matthew edel and Jerome Rothenberg, 1973, Macmillan, New York, p. 417-437.

6. Strotz, Robert H. Principles of urban transportation pricing. Highway Research Record, 1964, No 47.

7. Mohring, Herbert D. Urban Highway Investments. In: Pro ceedings Measuring Benefits of Government Investments. Robert Dorfinan, papers presented at a Conference of Experts held November 7-9, 1963, The Brookings Institution, Washington, D. C., p. 231-291.

8. Mohring, Herbet $D$. The peak load problem with increasing returns and pricing constraints. American Economic Review, September, 1970, Vol 60, No 4, p. 693-705.

9. Mohring, H. and Anderson, D. Congestion costs and congestion pricing. University of California, Irvine (Working paper), March 1996.

10. Lvy-Lambert, H. Tarification des services qualit variable: application aux pages de circulation. Econometrica, 1968, $36(3-4)$, p. $564-574$.

11. Marchand, N. A note on optimal tolls in on imperfect environment. Econometrica, 1968, 36(3-4), p. 575-581.

12. Vickrey, William S. Congestion Charges and Welfare: Some answers to Sharp's Doubts. Journal of Transport Economics and Policy, January, 1968, Vol 2, No 1, p. 107-118.

13. Small, Kenneth, A. A new highway pricing and investment policy. Washington: The Brooking Institution, 1989.

14. Small, Kenneth, A. The incidence of congestion tolls on urban highways. Journal of urban economics, 1983, Vol 13 , p. $90-111$.

15. Small, K. A. Urban Transportation Economics. Fundamentals of Pure and Applied Economics. 1992 a. Harwood, Chur.

16. De Vany, A. Uncertainty, waiting time, and capacity utilization: A stochastic theory of product quality. Journal of Political Economy, 1976, 84, p. 523-540.

17. Jensen, M. W. and Ross. Hydrogen as a transportation fuel. Environmental, 2001, Vol 43, No 3.

18. Vickrey, William S. Congestion theory and transport investment. Ant. Econ. Rev., 1969, Vol 59, p. 251-60.

19. Richard, Arnott; Marvin, Kraus. When are anonymous congestion charges consistent with marginal cost pricing? Journal of Public Economics, 1998, Vol 67 (1), p. 45-64, Copyright (c) Elsevier Science B. V.

20. De Palma, A.; Lindsey, R. Information and usage of congestible facilities under different pricing regimes. $\mathrm{Ca}$ nadian Journal of Economics, 1998, 31(3), p. 666-692.

21. De Palma, A. and Lindsey, R. Private toll roads: competition under various ownership regimes. Annuals of Regional Science, 2000, 34(1), p. 13-35. 
22. Economic on Social Commission for Asia and Pacific. Asia Institute of Transport Development. Sustainable Transport Pricing and Charges. Principles and Issues. United Notion, 2000 , p. $28-87$.

23. Social costs. Draft report of the task force on the social costs of transport. European Conference of ministers of transport. Committee of deputies, 1997. Brussels, p. 37 -56, p. 136-147, p. 94-120.

24. Towards fair and efficient pricing in transport - policy options fort internalizing the external costs of transport in the European Union - green paper. European Commission, Belgium, 1996, p. 34.

25. External costs of transport. Accident, environmental and congestion costs in Western Europe. Zurich/Karlsruhe, March 2000, p. 2-3.

26. External costs of transport in externe. Edited by P. Bichel, S. Schmid, W. Krewitt, R. Freidrich, IER, Germany, 1997, p. 4.
27. Gudmundsson, H. and Hojer, M. Sustainable development principles and their implications for transport. Ecological economics, 1999, Vol 19 (3), p. $269-282$.

28. Mozzarino, M. The economics of the greenhouse effect: evaluating the climate charge impact due to the transport sector in Italy. Energy policy, 2000, Vol 28, No 13, p. 957 966.

29. Nash, C. et al. Modifying transport prices to internalise externalities: evidence from European case studies. Regional science and urban economics, 2001, Vol 31, No 4, p. 413431.

30. Sperling, Daniel and Shaheen, Susan A. Transportation and energy: strategies for a sustainable transportation system. Berhley, CA: American Council for energy - efficient environment, 1995.

31. Feitelson, E. Introducing environmental equity dimensions into the sustainable transport discourse: issues and pitfalls. Transport and environment, 2002, Vol 7, No 2, p. 99 -- 118. 